\title{
Natural diets of zooplankton off southern California
}

\author{
G. S. Kleppel ${ }^{1}$, D. Frazel ${ }^{1}$, R. E. Pieper ${ }^{2}$, D. V. Holliday ${ }^{3}$ \\ ${ }^{1}$ Nova University Oceanographic Center, 8000 North Ocean Drive, Dania, Florida 33004, USA \\ ${ }^{2}$ University of Southern California Marine Laboratory, 820 South Seaside Avenue, Terminal Island, California 90731, USA \\ ${ }^{3}$ Tracor Applied Sciences, 9150 Chesapeake Drive, San Diego, California 92123, USA
}

\begin{abstract}
Plant and animal carotenoid pigments were isolated from the guts of the copepods Calanus pacificus and Clausocalanus sp. and the cladocerans Evadne spp. by high performance liquid chromatography. Measured carotenoid concentrations were converted to estimates of class-specific phytoplankton biomass and total microzooplankton biomass in the zooplankton diets. Different pigments were present in the guts at different times of day and night and the timing of peak gut fullness varied between species. In $C$. pacificus, pigment concentrations were highest during the period from evening twilight to midnight. Evadne spp. exhibited a midnight peak in gut pigmentation. Clausocalanus sp. contained elevated levels of pigments between midnight and noon. The gut contents of C. pacificus and Evadne spp. were dominated by animal carbon when phytoplankton biomass and productivity were relatively low, and by algal carbon when phytoplankton biomass and productivity were high. Clausocalanus sp. did not follow this pattern. Our observations are consistent with the hypothesis that carnivory may represent an important mode of feeding among small zooplankton and, further, that the diets of some species of zooplankton vary in response to quantitative and qualitative attributes of the food environment.
\end{abstract}

\section{INTRODUCTION}

Many small, planktonic crustaceans are thought to be omnivorous (Marshall 1924, Anraku \& Omori 1963, Mullin 1966). In addition to phytoplankton, these animals can ingest detritus (Heinle et al. 1977, Roman 1977, Boak \& Goulder 1983, Roman et al. 1983, Downs \& Lorenzen 1985) and microzooplankton (Lonsdale et al. 1979, Turner \& Anderson 1984, Stoecker \& Sanders 1985, Dagg \& Walser 1986, Sheldon et al. 1986, Sherr et al. 1986, Conley \& Turner 1987, Stoecker \& Egloff 1987).

Diversity in zooplankton diets may introduce nutritional variability. This, in turn, may affect such processes as growth and egg production (Checkley 1980, Durbin et al. 1983, Ambler 1985). For example, differences in the egg production rate of the copepod Acartia tonsa have been attributed to the classes of cultured phytoplankton (diatoms, dinoflagellates) that were used as food (Morey-Gaines 1980), to the use of cultured phytoplankton versus cultured microzooplankton as food (Stoecker \& Egloff 1987) and to seasonal variations in the natural diet (Kleppel 1987). Roman (1984) observed better survival and more rapid development of $A$. tonsa when its diet consisted of a mixture of diatoms and detritus than when either food was provided alone.

Little is known, however, about the natural diets of most planktonic crustaceans. Attempts to describe zooplankton diets in situ have frequently involved the determination of plant pigment concentrations in the gut (Mackas \& Bohrer 1976, Hallegraeff 1981, Kleppel \& Manzanilla 1983, Kleppel \& Pieper 1984). Such measurements, however, emphasize the herbivorous aspects of feeding and provide little or no indication of the importance of other dietary components.

In the study described here, plant and animal carotenoid pigments were extracted from the guts of zooplankton and used to infer the quantities and kinds of particles that had been ingested. Carotenoids occur extensively among marine plants and animals (Davies 1965, Herring 1972) and are commonly used as taxonomically-specific biomass analogs for planktonic organisms (Strain et al. 1944, Jeffrey 1974, LiaaenJensen 1979, Gieskes \& Kraay 1986, Smith et al. 1987).

Carotenoids and their principal metabolic transformation products seem to be reliable tracers of certain trophodynamic processes in the sea (Kleppel 1988). 
They can be chromatographically detected and quantified in zooplankton gut contents and fecal pellets on a semi-routine basis (Hallegraeff 1981, Repeta \& Gagosian 1982, Kleppel \& Pieper 1984, Nelson 1986). Although carotenoid digestion and metabolism are not yet completely understood, it appears that carotenoids do not degrade in the copepod gut (Nelson 1986). However, different kinds of zooplankton may metabolize ingested carotenoids in different ways (Repeta \& Gagosian 1983, Klein et al. 1986, Nelson 1986).

Most carotenoids, whether metabolically transformed or not, appear to remain in the measurable pigment pool while in the guts of crustaceans. The ubiquitous algal pigment beta-carotene is thought to be the only carotenoid that is assimilated by copepods (Paanakker \& Hallegraeff 1978, Ringelberg 1980). Beta-carotene is utilized by copepods in the biosynthesis of tissue carotenoids (Castillo et al. 1982).

Tissue carotenoids, such as astaxanthin, occur in crustaceans (Castillo et al. 1982), protistans (Tuttle et al. 1973, Balch \& Haxo 1984) and other macro- and microzooplankton. They quench singlet excited oxygen which is responsible for photo-peroxidation of proteins (Krinsky 1971). Such reactions can be induced by $10 \%$ or more of the incident solar radiation (Hairston 1979). Thus, animals in the upper water column (espe- cially those that do not migrate) should be rich in carotenoids.

The tissue carotenoid concentration of an animal is not always apparent from the extent to which it is 'colored' or pigmented. Color seems to be largely the result of carotenoid chemistry (i. e. binding, oxidative state, interactions with other carotenoids), while carotenoid concentration is thought to be, in part, a functional metabolic response to light and possibly other variables (Cheeseman et al. 1967, Hairston 1979, Ringelberg 1980, Byron 1982).

In this study we measured carotenoids extracted from small particles (nano- and microplankton) present in the waters off southern California, USA, and from material in the guts of copepods and cladocerans collected in these waters. We have converted the carotenoid data to estimates of phytoplankton and microzooplankton biomass and have evaluated the importance of carnivory in the diets of macroznoplankton from different food environments.

\section{METHODS}

Sampling. Plankton was sampled in the San Pedro Basin, California (Fig. 1) on 6, 11 and 12 March 1987 from RV 'New Horizon' (Scripps Institution of

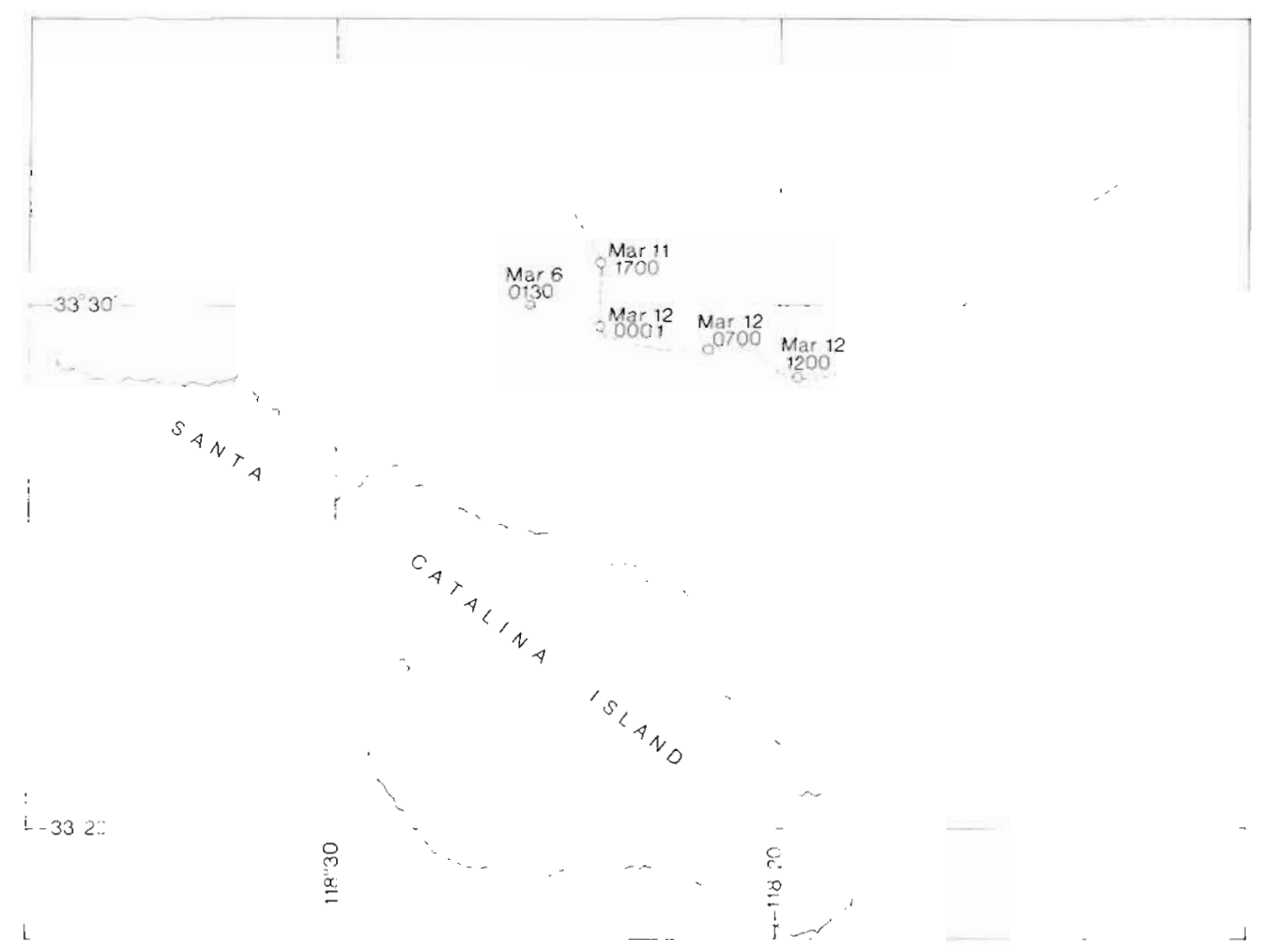

Figy. 1. Sampling locations in the San Pedro Basin, California, USA, 6 and 11-12 Mar 1987. Dashed line shows the track of a drogue centered at $20 \mathrm{~m}$ between 11. and $12 \mathrm{Mar}$ 
Oceanography), while the ship followed a drogue centered at $20 \mathrm{~m}$. Zooplankton was collected from the upper mixed layer by hauling a net $10.5 \mathrm{~m}$ mouth diameter, $202 \mu \mathrm{m}$ Nitex mesh) vertically from $30 \mathrm{~m}$ to the surface at $01: 30 \mathrm{~h}$ on $6 \mathrm{March}$, at 17:00 h (nautical twilight) on 11 March, and at 00:01 h, 07:00 h (twilight) and 12:00 h on 12 March.

Samples were immediately split into halves and the animals in one fraction were narcotized with carbonated water (Kleppel et al. 1988). The zooplankton in the other fraction was transferred, on $202 \mu \mathrm{m}$ mesh screen, to GF/F filtered seawater for $3.5 \mathrm{~h}$ to permit gut evacuation to occur. Microscopic examination of the guts of some of these animals following the evacuation period revealed that most guts were either completely empty or contained small amounts of material in the hindgut. The narcotized animals (which did not evacuate their guts) were transferred to $100 \mu \mathrm{m}$ mesh screens and frozen in liquid nitrogen. After the gut evacuation period, the animals in filtered seawater were also transferred to screens and frozen.

Water samples (2 l) pumped from discrete depths were passed through GF/C filters and the particles retained on the filters were stored in liquid nitrogen. Periodically, seawater subsamples were preserved with Lugol's iodine for microscopic enumeration of nano- and microplankton (i.e. phytoplankton and microzooplankton).

${ }^{14} \mathrm{C}$-primary productivity was measured on each sampling date. Replicate light and dark bottles $(250 \mathrm{ml})$ were filled with water from 6 isolume depths, inoculated with $5 \mu \mathrm{Ci}$ of $\mathrm{NaH}^{14} \mathrm{CO}_{3}$ and placed into bags made from layers of fiberglass screen to simulate the light intensities of the collection depths (Hitchcock 1986). The samples were incubated on deck for 4 to $6 \mathrm{~h}$ in clear plexiglass cylinders through which near-surface water circulated continuously. After incubation, the samples were filtered under low vacuum $(<50 \mathrm{~mm}$ $\mathrm{Hg}$ ) and rinsed with filtered seawater without exposure to air. The filters were acidified with $0.5 \mathrm{~N} \mathrm{HCl}$ for $1 \mathrm{~h}$, then immersed in $3 \mathrm{ml}$ of Aquasol 2 scintillation cocktail (New England Nuclear Corp.) for counting.

Pigment analysis. Plankton samples collected during the cruise were analyzed for pigment content by reverse-phase high performance liquid chromatography (HPLC). HPLC-grade solvents were degassed and filtered prior to use. Pigments were extracted in a cool, dimly lit room.

Similar sized individuals of the dominant zooplankton species were sorted from the frozen screens for analysis. The species studied were the copepod Calanus pacificus (late copepodites, length 2.5 to $2.7 \mathrm{~mm}$ ), cladocerans Evadne nordmanii and E. spinifera, which were combined as Evadne spp., and several small (length 0.9 to $1.0 \mathrm{~mm}$ ) copepods that were dominated by Clausocalanus sp., but which may have included individuals of the genera Ctenocalanus and Paracalanus. These could not be differentiated on frozen Nitex screens.

The zooplankton were transferred by species (or species group) to $2.5 \mathrm{~cm}$ GF/C filters and immersed in 1 to $2 \mathrm{ml}$ of $90 \%$ aqueous acetone. The filters containing phytoplankton and microzooplankton samples were also immersed in $90 \%$ aqueous acetone. The samples were macerated with hand-operated tissue grinders, while being held on ice. After thorough grinding, the samples were refrigerated in the dark for $60 \mathrm{~min}$, then centrifuged for 5 min to remove particulates. Each extract was decanted into a clean, graduated cen-

Table 1. Carotenoids measured in phytoplankton and zooplankton

\begin{tabular}{|c|c|c|c|c|c|c|}
\hline Pigment & $\begin{array}{l}\text { Golden brown } \\
\quad \text { algae }\end{array}$ & Dinoflagellates & $\begin{array}{l}\text { Green } \\
\text { algae }\end{array}$ & Prymnesiophytes & Animals & Detritus \\
\hline Peridinin & & + & & & & \\
\hline Fucoxanthin & + & & & + & & \\
\hline $19^{\prime}$-hexanoyl-fucoxanthin ${ }^{d}$ & & + & & + & & \\
\hline Lutein $^{b}$ & & & + & & & \\
\hline Astaxanthin ${ }^{\mathrm{C}}$ & & & & & + & \\
\hline Canthaxanthin ${ }^{\mathrm{C}}$ & & & & & + & \\
\hline Echinenone $^{c}$ & & & & & + & \\
\hline Peridininol $^{\mathrm{d}}$ & & & & & & + \\
\hline Fucoxanthinol $^{e}$ & & & & & & + \\
\hline \multicolumn{7}{|c|}{${ }^{a}$ Limited occurrence in the dinoflagellates } \\
\hline \multicolumn{7}{|c|}{$\begin{array}{l}{ }^{b} \text { Green algal pigments (including chlorophyll b) were not detected in any samples, though they were observed, at low } \\
\text { concentrations, at other times during the cruise }\end{array}$} \\
\hline \multicolumn{7}{|c|}{$\begin{array}{l}\text { c Animal carotenoids were detected, and their concentrations calculated, individually. Concentrations were then summed and } \\
\text { are reported as total animal carotenoids. Heterotrophic dinoflagellates, considered animals in this study, may contain one or } \\
\text { more of these pigments }\end{array}$} \\
\hline \multicolumn{7}{|c|}{ d A transformation product of peridinin thought to be produced through digestion by certain heterotrophs } \\
\hline
\end{tabular}


trifuge tube and an ion pairing agent, consisting of $1.5 \mathrm{~g}$ of tetra- $n$-butyl ammomium acetate $+7.7 \mathrm{~g}$ of ammonium acetate per $100 \mathrm{ml}$ of water (Solution P of Mantoura \& Llewellyn 1983), was added in a ratio of $0.3 \mathrm{ml}$ Solution $\mathrm{P} \mathrm{ml}^{-1}$ extract. The extracts were agi-
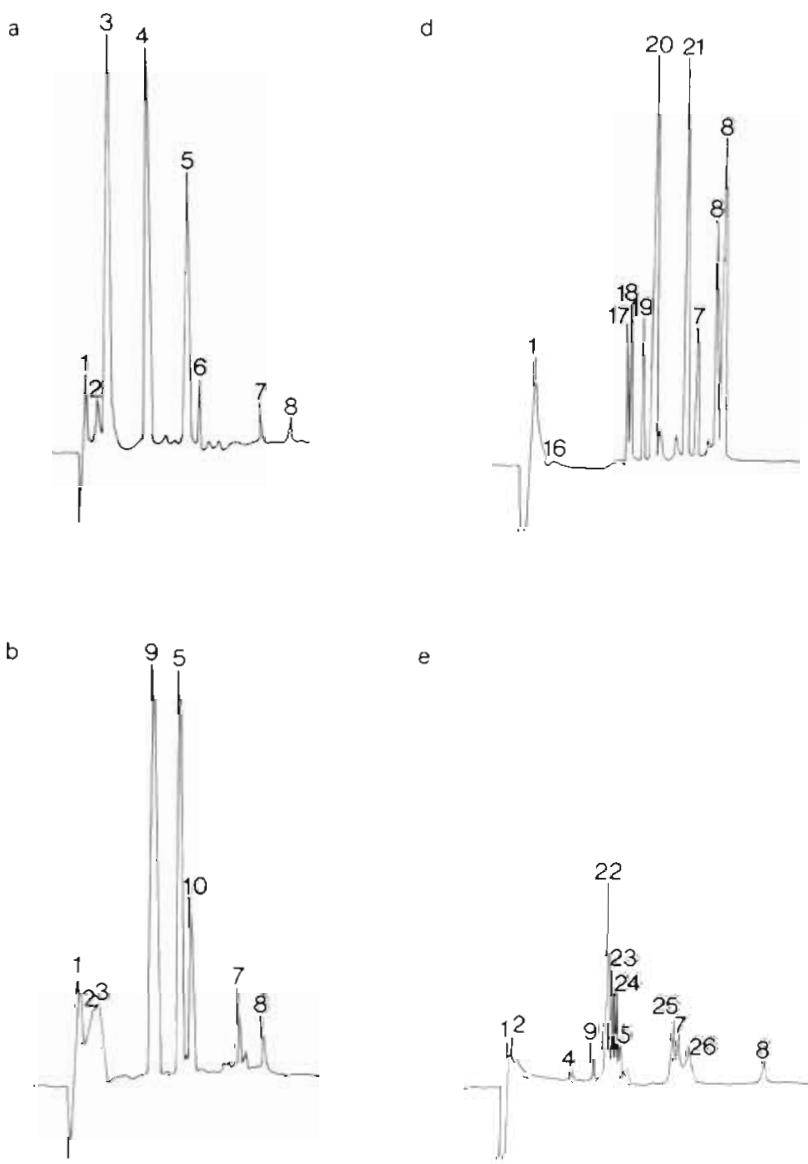

e

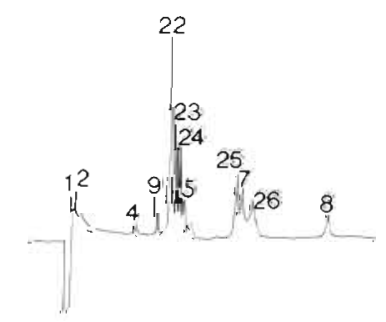

C

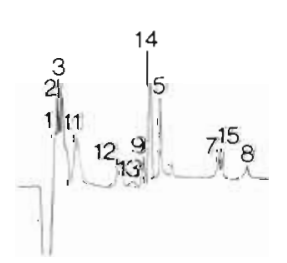

tated and set aside in darkness for at least 5 min to permit the ion pairing agent to bind appropriately.

A Waters gradient elution HPLC system, consisting of a model 680 gradient controller, paired model 501 pumps, and a U6K injector, was used to elute pigments from a Beckman, C8 octyl-ultrasphere column (15 cm $\times 1.5 \mathrm{~mm}$, stainless steel; with octyl-ultrasphere guard columni $>40000$ theoretical plates) with a continuous, 2-solvent gradient. Pigments were detected with a Waters model 481 variable wavelength, UV/vis detector and the signal was plotted and integrated on a Waters model 730 data module.

Solvent 1 , a solution of water, methanol and Solution $\mathrm{P}(8: 1: 1)$, was mixed with Solvent 2 , a solution of methanol and acetone $(8: 2)$, in decreasing proportion from $20 \%$ Solvent 1:80\% Solvent 2 , to $100 \%$ Solvent 2 over $10 \mathrm{~min}$, while the flow rate was increased from $1.0 \mathrm{ml} \mathrm{min}^{-1}$ to $1.9 \mathrm{ml} \mathrm{min}^{-1}$. Solvent 2 was delivered at a flow rate of $1.9 \mathrm{ml} \mathrm{min}{ }^{-1}$ for an additional $10 \mathrm{~min}$.

Numerous chlorophyll and carotenoid pigments can be detected by HPLC. Our interest, however, was in those carotenoids that can be utilized as taxonomic markers of classes or groups of classes of phytoplankton and microzooplankton. Carotenoids used as taxonomic markers in this study are shown in Table 1. Chromatographically isolated pigments were identified by their characteristic retention times (RT) and capacity factors $\left(k^{\prime}\right)$. RT and $k^{\prime}$ values were determined from chromatograms of pigment standards prepared from algal cultures and copepod tissues (Fig. 2). Chlorophyll $c_{1}$ and $c_{2}$, and $19^{\prime}$-butanoyl-fucoxanthin were identified by Dr R. R. Bidigare from chromatograms of pigment standards that we prepared. These identifications are tentative and the pigments were not used as markers in the present study.

To determine the concentration of each pigment in the chromatograms, the area under the peak created by each pigment was multiplied by a pigment-specific concentration:peak-area ratio, then scaled to sample size. The area under each peak is proportional to pigment concentration (Snyder \& Kirkland 1979) and peak area varies linearly with concentration in all pigment standards that we have measured. Concentration:peak-area ratios were generated by chromatographing serial dilutions of each pigment standard, collecting the pigment as it eluted and measuring its absorbance at $440 \mathrm{~nm}$ with an IBM Instruments, Inc., model 9410 scanning spectrophotometer equipped with small-volume cuvettes (volume $=0.9 \mathrm{ml}$; pathlength $=1 \mathrm{~cm}$ ). The measured absorbances of plant pigments were converted to concentration estimates with extinction coefficients from Mantoura \& Llewellyn (1983). The extinction coefficient for astaxanthin, given by Hairston (1979), was used to estimate the concentrations of all 3 animal carotenoids because we 
have found no extinction coefficients for canthaxanthin or echinenone in the literature. This procedure introduces an error into the calculation of animal carotenoid concentration. However, in the present study the error was probably small because astaxanthin was overwhelmingly the dominant animal pigment in our samples.

Microplankton biomass estimates from pigments. Carotenoid concentrations tend to be proportional to the biomass of the taxonomic groups in which they occur (Liaaen-Jensen 1979, Smith et al. 1987). However, the specific relationship between one carotenoid and carbon biomass is likely to be different from the relationship between another carotenoid and carbon biomass. In addition, physiological and environmental variables can affect the $\mathrm{C}$ :carotenoid ratio both within and between taxonomic groups. Therefore, to use pigments as biomass analogs, a specific carotenoid-tocarbon conversion must be determined for each pigment.

To determine the C:carotenoid ratios of the major taxonomic groups of phytoplankton in the water and in the gut contents of the macrozooplankton, the seawater subsamples that had been preserved for microscopic analysis were counted (at $400 \times$ magnification) and phytoplankton cell dimensions were measured with an ocular micrometer. The cell plasma volume of each species was calculated from these measurements and converted to estimates of cellular carbon concentration (Strathmann 1967). Estimates of diatom and chrysophycean $C$, dinoflagellate $C$, and prymnesiophycean $C$ were made by summing the carbon estimates for the species within each phytoplankton class. The ratio of class-specific $\mathrm{C}$ to the measured concentration of the carotenoid used as a biomass analog was then generated (Table 2).

The relationship between the concentrations of carbon and animal pigments in the microzooplankton was evaluated in 2 ways. First, microzooplankton samples were collected by pumping water through a $200 \mu \mathrm{m}$ mesh screen and then a $64 \mu \mathrm{m}$ mesh net. The material retained by the smaller mesh was composed of larger microzooplankton, including crustacean larvae, large ciliates, mollusc veligers and polychaete trochophores. Phytoplankton cells were not abundant.

Each sample was split, and one fraction was dried $\left(60^{\circ} \mathrm{C}\right.$ for $\left.24 \mathrm{~h}\right)$ and weighed. The animal carotenoids in the other fraction were separated from plant xanthophylls (Kleppel et al. 1985) and measured spectrophotometrically. Dry weights (DW) were converted to estimates of zooplankton carbon using the equation of Weibe et al. (1975):

$$
\log \mathrm{DW}=0.977 \log \mathrm{C}+0.508 .
$$

Therefore,

$$
\log C=1.02 \log D W-0.520 .
$$

The second prodecure involved collecting microzooplankton by pumping water through a $100 \mu \mathrm{m}$ mesh screen and a $20 \mu \mathrm{m}$ mesh screen. The material retained by the $20 \mu \mathrm{m}$ mesh, which contained small ciliates, dinoflagellates, some copepod nauplii and phytoplankton, was subsampled for HPLC pigment analysis and microscopic enumeration. Heterotrophs were counted and measured, and carbon concentrations were calculated from cell volumes (Beers \& Stewart 1970).

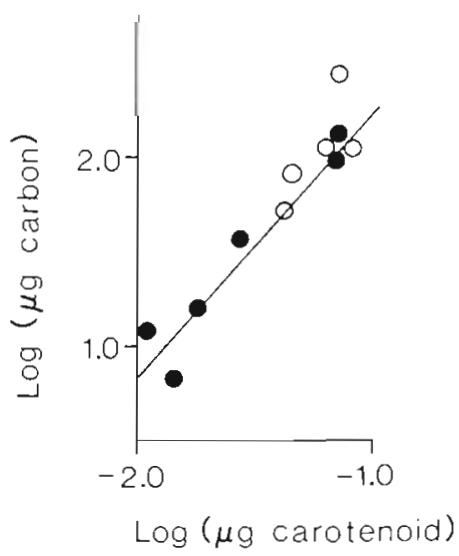

Fig. 3. Regression of estimated microzooplankton carbon biomass on animal carotenoid content. ( ) Samples collected in a $64 \mu \mathrm{m}$ mesh net in which carbon content was estimated from dry weight. (0) Samples collected on a $20 \mu \mathrm{m}$ mesh screen in which carbon content was estimated from microscopic analysis

Table 2. Carbon:carotenoid ratios for marker pigments of 3 phytoplankton classes from the upper $40 \mathrm{~m}$ of the water column in San

\begin{tabular}{|c|c|c|c|c|}
\hline Taxonomic group & Marker pigment & $\begin{array}{l}\text { C:carotenoid } \\
\text { ratio }(w: w)\end{array}$ & Confidence interval & $N$ \\
\hline Bacillariophyceae ${ }^{a}$ & Fucoxanthin & 42.6 & $39.2-46.0$ & 3 \\
\hline Dinophyceae & Peridinin & 323.2 & $281.8-364.6$ & 3 \\
\hline Prymnesiophyceae & $19^{\prime}$-hexanoyl-fucoxanthin & 15.4 & $12.9-17.9$ & 3 \\
\hline
\end{tabular}
Pedro Basin, California, March 1987. Samples were collected at 2, 20 and $40 \mathrm{~m}$ 
The data that resulted from the 2 sets of measurements were pooled and the relation between carbon biomass, $C$, and carotenoid content, P, was determined by regression analysis (Fig. 3). The equation for the relation was,

$$
\log C=1.54 \log P+3.88
$$

where $\mathrm{C}$ and $\mathrm{P}$ are expressed in $\mathrm{mg}$. This equation explains $85 \%$ of the variance in the data $(p<0.001)$ with a standard error of 0.12 .

To distinguish zooplankton tissue carotenoids from the carotenoids of microzooplankton in their guts, the pigment levels of the zooplankton that were starved in filtered seawater were subtracted from the pigment levels of the zooplankton that were not starved. The tissues should have been the principal source of animal carotenoids in the starved zooplankton. In the zooplankton that were frozen immediately, both tissues and gut contents should have contributed pigments. Thus, the difference was taken as the gut pigment level.
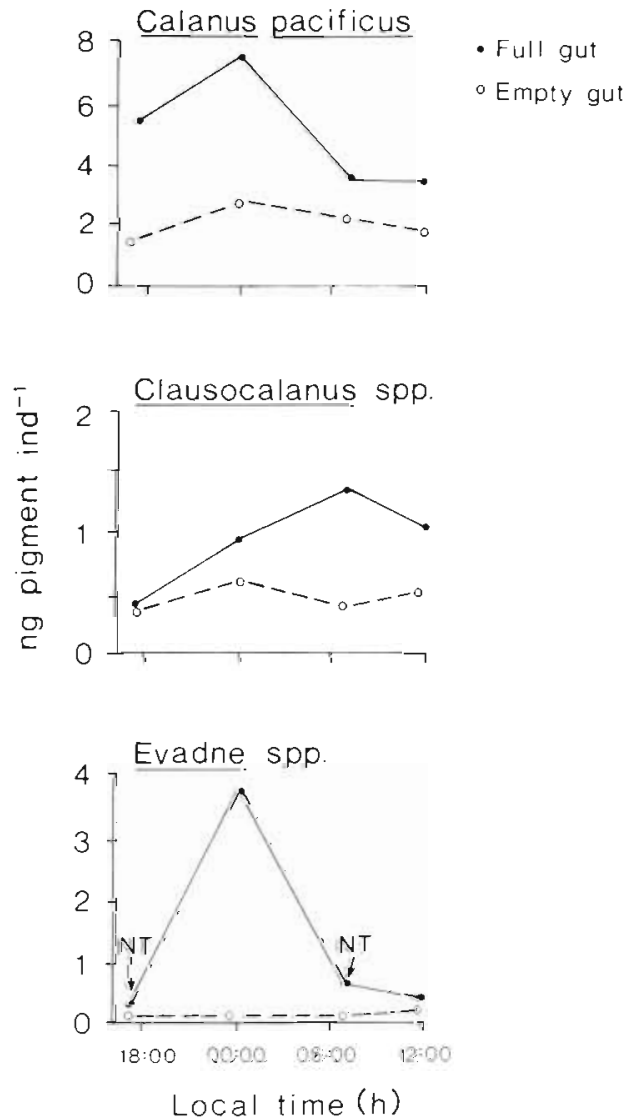

Fig. 4. Concentrations of animal pigments in zooplankton that were frozen immediately upon collection ( $\bullet$, and in starved zooplankton (c). Samples collected 11-12 Mar 1987 NT: Nautical twilight
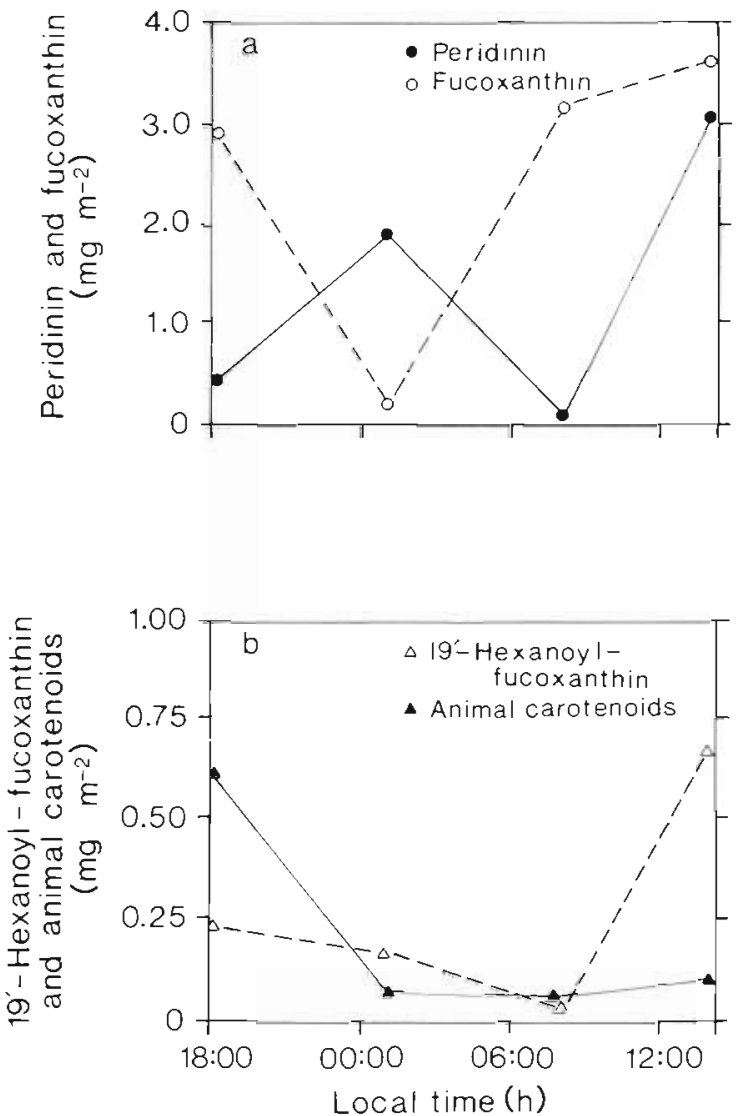

Fig. 5. Depth-integrated carotenoid concentrations from phytoplankton and microzooplankton samples collected through the upper $40 \mathrm{~m}$ of the water column during a time series in San Pedro Basin, 11-12 Mar 1987. (a) Fucoxanthin and peridinin; (b) 19' -hexanoyl-fucoxanthin and animal carotenoids. Choice of pigments to plot together was based simply upon typical concentrations encountered

\section{RESULTS}

\section{Gut versus tissue pigments}

Diel cycling of carotenoids in zooplankton body tissues has been reported in a few studies (Hallegraeff et al. 1978, Ringelberg 1980, Kleppel et al. 1985, but see Hairston 1980) and we evaluated the possibility that such changes occurred during the present investigation. Animal carotenoid levels in the zooplankton that had not evacuated their guts varied 2- to 8-fold in the series of samples collected on 11-12 March. Carotenoid levels were less variable in the zooplankton that were starved in filtered seawater (Fig. 4). Thus, the major diel variations in animal carotenoid content appear to have been due to changes in animal carotenoid levels in the gut rather than to the cycling of carotenoids in the body tissues 


\section{Time series measurements}

Although plankton samples for pigment analysis were collected at discrete depths in the water column, integrated values are presented (Fig. 5) to maintain consistency with net-integrated zooplankton gut contents data. In vivo fluorescence profiles performed during the cruise frequently indicated that a chlorophyll maximum was present at 30 to $50 \mathrm{~m}$. The distribution of carotenoids in our discrete samples in the upper $40 \mathrm{~m}$ also increased with depth.

Between 11 and 12 March, water column pigment concentrations were notably low in the upper $40 \mathrm{~m}$. Levels of fucoxanthin (mostly from Bacillariophyceae), 19'-hexanoyl-fucoxanthin (Prymnesiophyceae) and animal carotenoids all declined during the night. Conversely, peridinin (Dinophyceae) concentrations, which were low at dusk, rose to a peak in the middle of the night, then fell at dawn $(07: 00 \mathrm{~h})$. Concentrations of all plant carotenoids increased during the day. Animal carotenoid levels, however, remained low.

Zooplankton gut contents contained both plant and animal pigments (Fig. 6). Gut pigment composition varied temporally within each species and the timing of peak gut fullness varied between species.

Calanus pacificus contained elevated levels of fucoxanthin (Bacillariophyceae) and animal pigments at evening twilight and midnight. Peridinin (Dinophyceae) concentrations were high only at midnight and 19'-hexanoyl-fucoxanthin (Prymnesiophyceae) was present only at morning twilight.

In Evadne spp., the concentrations of all microplankton pigments increased to a single peak at midnight, after which the gut was nearly empty. Conversely, the guts of Clausocalanus sp. contained pigments during an extended period between midnight and noon, with

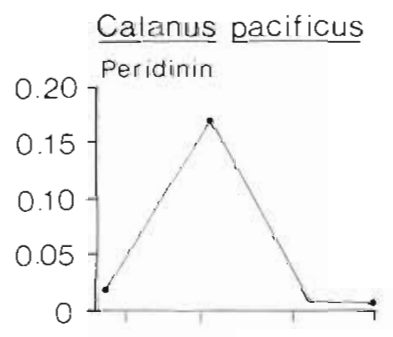

Evadne spp.

Clausocalanus sp.
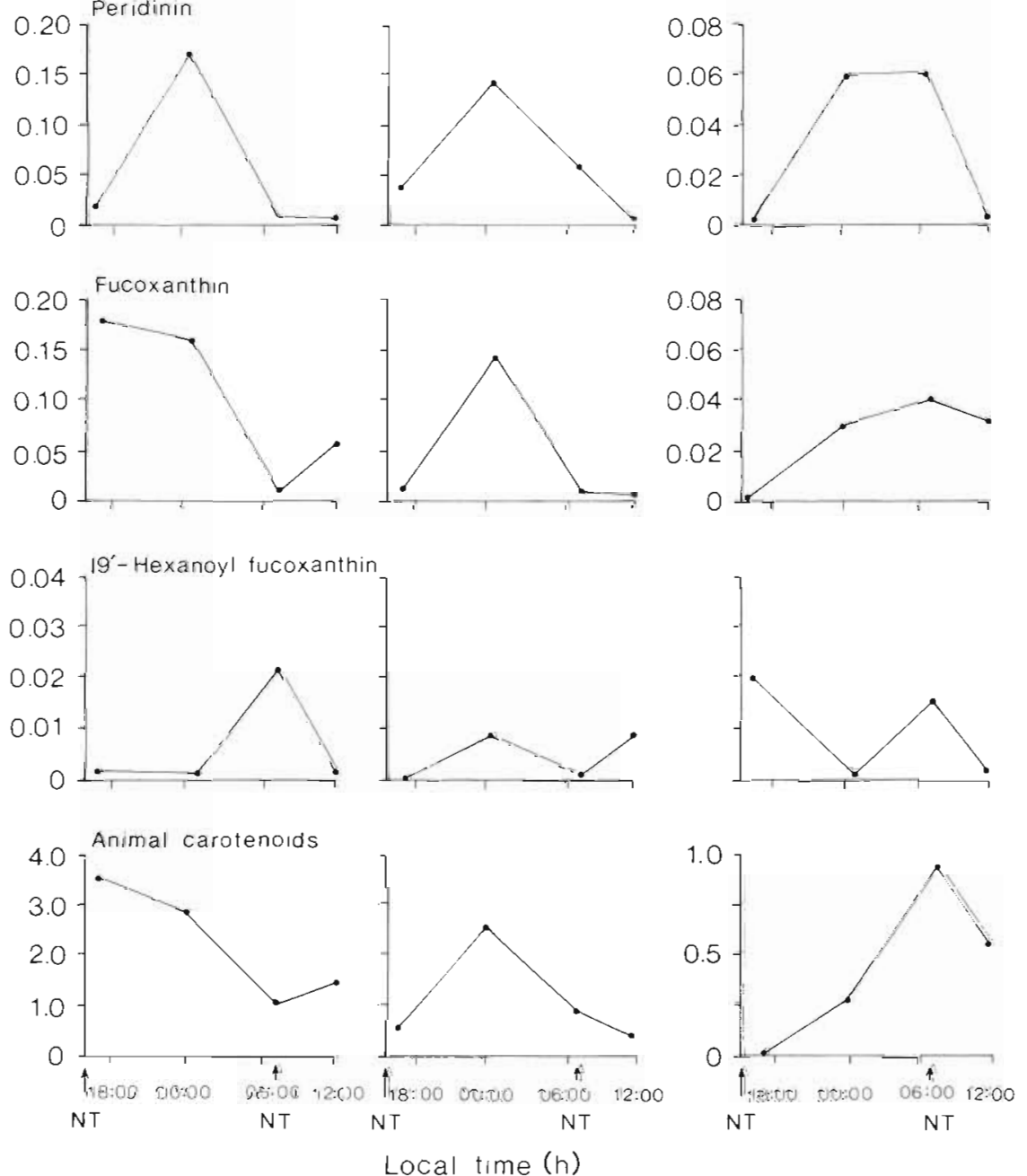

Fig. 6. Carotenoid concentrations ( $\mathrm{ng}$ ind $^{-1}$ ) in the guts of zooplankton collected from the upper $30 \mathrm{~m}$ on $11-12 \mathrm{Mar} 1987$ 
a peak at 07:00 h. Peridinin levels were elevated at midnight and morning twilight; diatom and animal pigments were present in the midnight, morning and noon samples. The prymnesiophycean pigment was present at both evening and morning twilights. This diel persistence of food in the gut of Clausocalanus was observed in an earlier study of gut fluorescence performed in the same region of the San Pedro Basin (unpubl.).

Zooplankton gut carbon contents estimated from carotenoid concentrations are presented in Table 3. Although the confidence limits on these estimates are wide, it is evident that microzooplankton biomass dominated the diets of the macrozooplankton sampled between 11 and 12 March. In all but one case (Clausocalanus sp., 17:00 h), microzooplankton is estimated to have contributed $>50 \%$ of the total planktonic carbon to the gut contents. In $58 \%$ of the samples (7 out of 12 cases), microzooplankton carbon exceeded $90 \%$ of the total estimated planktonic carbon in the gut.

\section{Comparison of night-time profiles}

On 6 March, primary productivity was 4 times higher than on 11 March, and 2 times higher than on 12 March. Depth-integrated phytoplankton biomass was 1.8 times higher on the night of 6 March (01:30 h) than on the night of 11-12 March (midnight samples) (Table $4 \mathrm{~A})$.

The gut pigment compositions of all 3 species were markedly different on the 2 nights (Table $4 \mathrm{~B}$ ). Calanus pacificus and Evadne spp. guts contained greater proportions of algal (particularly dinoflagellate) carbon than animal carbon on 6 March, though the paucity of pigment in the guts of Evadne suggests that the cladoceran was not feeding intensely at the time of sampling. Conversely, carotenoid analysis indicates that Clausocalanus sp. contained principally animal material in its gut on 6 March.

\section{DISCUSSION}

The salient feature of this study is the apparent importance of microzooplankton in the diets of small copepods and cladocerans. Although little is known about the occurrence of carnivory among most planktonic crustaceans, evidence is accumulating to suggest that certain species, long thought to be herbivores, or predominantly herbivorous omnivores, may, in fact, feed intensely on microzooplankton (Gifford \& Dagg 1987). Stoecker \& Egloff (1987) reported that, in the presence of certain kinds of ciliates, the filtration rate of Acartia tonsa was an order of magnitude higher than typically observed in the presence of algae.

Initially, it was surprising that Evadne spp. contained animal material in its gut. Cladocerans are considered to be important grazers of nanoplanktonic algae (Falkowski et al. 1983) but are less often thought of as predators. However, heterotrophs may compose on the order of 20 to $50 \%$ of the nanoplankton in certain regions (Rassoulzadegan \& Sheldon 1986). Heterotrophic nanoplankton would likely be ingested by the same zooplankton that consume small autotrophs.

The tendency for carnivory by Calanus pacificus and possibly Evadne spp. was substantially lower on 6 March, when phytoplankton biomass and production were high, than on 11-12 March, when biomass and production were low (Table 4 ). The ability of zooplankton to alter their diets in response to the food environment has been documented in a number of studies. The presence or relative proportions of phytoplankton and

Table 3. Estimated minimum and maximum plankton carbon concentrations in the gut contents of Calanus pacificus, Evadne spp. and Clausocalanus sp., based on confidence intervals for C: carotenoid ratios for phytoplankton (Table 2) and regression (Eq. 2) for microzooplankton. Also shown are percentages of microzooplankton $C$ relative to total microplankton $C$ in the guts during each sampling interval

\begin{tabular}{|c|c|c|c|c|}
\hline \multirow[t]{2}{*}{ Species } & \multicolumn{4}{|c|}{ Time (h) } \\
\hline & $17: 00$ & $00: 01$ & $07: 00$ & $12: 00$ \\
\hline \multicolumn{5}{|l|}{ Calanus pacificus } \\
\hline Dietary $C: \min -\max \left(\mu \mathrm{g}\right.$ ind.$\left.^{-1}\right)$ & $0.78-2.32$ & $0.54-1.62$ & $0.12-0.37$ & $0.19-0.57$ \\
\hline$\%$ Microzooplankton & 99.2 & 93.8 & 99.9 & 99.4 \\
\hline \multicolumn{5}{|l|}{ Evadne spp. } \\
\hline Dietary C: $\min .-\max .\left(\mu \mathrm{g}\right.$ ind..$\left.^{-1}\right)$ & $0.05-0.09$ & $0.48-1.37$ & $0.09-0.25$ & $0.01-0.39$ \\
\hline$\%$ Microzooplankton & 69.8 & 93.6 & 74.3 & 93.7 \\
\hline \multicolumn{5}{|l|}{ Clausocalanus sp. } \\
\hline Dietary C: $\min .-\max .\left(\mu \mathrm{g}\right.$ ind. $\left.{ }^{-1}\right)$ & $0.011-0.013$ & $0.03-0.07$ & $0.11-0.30$ & $0.04-0.13$ \\
\hline \% Microzooplankton & 0 & 55.3 & 88.2 & 98.3 \\
\hline
\end{tabular}


Table 4. Comparison of food environments and zooplankton diets on 6 and 11-12 March 1987. (A) Characteristics of the food environment in the upper $30 \mathrm{~m}$, with confidence intervals in parentheses; (B) Zooplankton diets

\begin{tabular}{|c|c|c|c|c|c|}
\hline \multicolumn{2}{|c|}{ (A) Food environment } & \multicolumn{2}{|l|}{6 Mar } & \multicolumn{2}{|c|}{$11-12 \mathrm{Mar}$} \\
\hline \multicolumn{4}{|c|}{ Nano- and microplankton carbon $\left(\mathrm{mg} \mathrm{m}^{-2}\right)$} & \\
\hline \multicolumn{2}{|c|}{ Dinoflagellates } & \multicolumn{2}{|c|}{$\begin{array}{c}1068.0 \\
(929.9-1203.1)\end{array}$} & \multicolumn{2}{|c|}{$\begin{array}{c}615.0 \\
(507.2-656.3)\end{array}$} \\
\hline \multicolumn{2}{|c|}{ Diatoms } & \multicolumn{2}{|c|}{$\begin{array}{c}204.0 \\
(189.0-220.8)\end{array}$} & \multicolumn{2}{|c|}{$\begin{array}{c}75.0 \\
(72.0-84.0)\end{array}$} \\
\hline \multicolumn{2}{|c|}{ Prymnesiophytes } & \multicolumn{2}{|l|}{$\begin{array}{r}6.0 \\
(5.0-7.0)\end{array}$} & \multicolumn{2}{|c|}{$\begin{array}{c}2.4 \\
(2.0-2.8)\end{array}$} \\
\hline \multicolumn{2}{|c|}{ Animal } & \multicolumn{2}{|c|}{$\begin{array}{c}699.0 \\
(392.8-1186.3)\end{array}$} & \multicolumn{2}{|c|}{$\begin{array}{c}552.0 \\
(316.7-956.5)\end{array}$} \\
\hline \multicolumn{2}{|c|}{ Primary productivity (mg C $\left.\mathrm{m}^{-3} \mathrm{~h}^{-1}\right)$} & \multicolumn{2}{|l|}{29.8} & \multicolumn{2}{|c|}{$\begin{array}{r}7.2^{\mathrm{a}} \\
11.5^{\mathrm{b}}\end{array}$} \\
\hline \multicolumn{6}{|c|}{ (B) Gut contents } \\
\hline \multirow[t]{2}{*}{ Species } & \multirow[t]{2}{*}{ Pigment } & \multicolumn{2}{|c|}{$6 \mathrm{Mar}$} & \multicolumn{2}{|c|}{ 11-12 Mar } \\
\hline & & $\begin{array}{l}\text { ng pig. } \\
\text { copepod }^{-1}\end{array}$ & $\% \operatorname{diet} \mathrm{C}$ & $\begin{array}{l}\text { ng pig. } \\
\text { copepod }^{-1}\end{array}$ & $\% \operatorname{diet} \mathrm{C}$ \\
\hline \multicolumn{6}{|c|}{ Calanus pacificus } \\
\hline & Peridinin & 0.51 & 74.5 & 0.17 & 5.5 \\
\hline & Fucoxanthin & 0.15 & 2.9 & 0.15 & 0.7 \\
\hline & 19 -hexanoyl-fucoxanthin & 0 & 0 & 0 & 0 \\
\hline & Animal & 0.41 & 22.6 & 2.89 & 93.8 \\
\hline \multicolumn{6}{|c|}{ Evadne spp. } \\
\hline & Peridinin & 0.03 & 85.1 & 0.14 & 5.6 \\
\hline & Fucoxanthin & 0.04 & 14.9 & 0.14 & 0.7 \\
\hline & $19^{\prime}$-hexanoyl-fucoxanthin & 0 & 0 & 0.01 & $<0.1$ \\
\hline & Animal & 0 & 0 & 2.52 & 93.6 \\
\hline \multicolumn{6}{|c|}{ Clausocalanus sp. } \\
\hline & Peridinin & $<0.01$ & 0.8 & 0.06 & 41.9 \\
\hline & Fucoxanthin & 0.02 & 1.8 & 0.03 & 2.8 \\
\hline & $19^{\prime}$-hexanoyl-fucoxanthin & 0 & 0 & 0 & 0 \\
\hline & Animal & 0.40 & 97.4 & 0.28 & 55.3 \\
\hline
\end{tabular}

microzooplankton in the environment seems to influence the tendency for carnivorous feeding in the copepods Calanus pacificus (Landry 1981), Acartia tonsa (Stoecker \& Sanders 1985) and Centropages hamatus (Conley \& Turner 1987). Dagg \& Walser (1986) reported from field and laboratory investigations that while Neocalanus plumchrus is predominantly herbivorous in the Bering Sea, it may obtain substantial nutrition by predation on microzooplankton in the subarctic Pacific Ocean. Periodically, the predatory copepod Corycaeus anglicus has been observed to feed on photosynthetic dinoflagellates (Kleppel \& Pieper 1984).

Attempts to apply our observations to animals in deeper waters should be undertaken with caution because zooplankton gut composition was measured only in specimens collected only from the upper $30 \mathrm{~m}$. Microzooplankton concentrations off southern California frequently peak near the sea surface and decline sharply with depth (Beers 1986). Thus, there may be a greater tendency for carnivorous feeding near the surface than at depth. Among zooplankton species that feed in the surface waters, periods of intense carnivory may be quite typical.

Carotenoid levels in the phytoplankton and microzooplankton varied 10- to 32-fold during the 11-12 March time series (Fig. 5). Similar changes in pigment content were evident in the guts of the zooplankton (Fig. 6). Such variation is likely the result of both physical and biological forcing. Although we sampled 
along a drogue track, advection and mixing most likely influenced the observed pigment distributions

Biological variability, including diel changes in phytoplankton growth and pigment production rates, and diel changes in zooplankton feeding activities may also have influenced pigment distributions in the water column. The nocturnal decline in all pigments except peridinin, and the recovery of phytoplankton pigment levels during the day, seem consistent with expectations about diel cycles in grazing, predation and phytoplankton growth.

The present study helps to demonstrate the value of pigment markers for assessing the distributions and activities of planktonic organisms. However, many questions are as yet unresolved. Although animal pigments appear useful as microzooplankton biomass analogs, the proportionality between pigmented and unpigmented microzooplankton is unknown. Nor have microzooplankton taxonomic categories been distinguished by their pigments. Despite these limitations, microplankton carotenoids can now be measured precisely, on a semi-routine basis. As such, these pigments can provide useful information about planktonic food webs and trophic structures.

Acknowledgements. We thank J. Dawson, I Boatwright, $P$. Mull and V. Jennings, the Master and crew of RV 'New Horizon' and D. Newman and his staff at the USC Marine Support facility for assistance during the cruise. We also thank L. Brand for supplying the algal cultures from which carotenoid standards were prepared. R. R. Bidigare provided valuable assistance by interpreting some of the chromatograms, evaluating our HPLC methods and commenting on the manuscript. In addition, comments and suggestions by $\mathrm{M}$. J. Dagg, G. L. Hitchcock, J. M. Napp, P. Oertner, S. L. Smith and 3 anonymous reviewers on various drafts of the manuscript were most helpful and appreciated. K. Maxson drafted the figures. This work was supported by Grants OCE 84-15989 and OCE 87-45282 from the Biological Oceanography Program of the National Science Foundation.

\section{LITERATURE CITED}

Ambler, J. W. (1985). Seasonal factors affecting egg production and viability of eggs of Acartia tonsa Dana from East Lagoon, Galveston, Texas. Estuar. coast. Shelf Sci 20: 743-760

Anrak11, M. Omori, M. (1963). Preliminary survey of the relationship between the feeding habits and the structure of the mouthparts of marine copepods. Limnol. Oceanogr. 19: $446-451$

Balch, W. M., Haxo, F. T. (1984). Spectral properties of Noctiluca miliaris Suriray, a heterotrophic dinoflagellate. J. Plankton Res. 6: 515-525

Beers, J. R. (1986). Organisms and the food web. In: Eppley R. W. (ed.) Plankton dynamics in the southern California Bight. Springer-Verlag, New York, p. 84-175

Beers, J. R., Stewart, G. L. (1970). Part VI. Numerical abundance and estimated biomass of microzooplankton. In Strickland, J. D. H. (ed.) The ecology of the plankton off La Jolla, California, in the period April through September 1967. University of California Press, Berkeley, p. 67-87

Boak, A. C., Goulder, R. (1983). Bacterioplankton in the diet of the calanoid copepod Eurytemora sp. in the Humber estuary. Mar. Biol. 73: 139-149

Byron, E. R. (1982). The adaptive significance of calanoid copepod pigmentation: a comparative experimental analysis Ecology 63: 1871-1886

Castillo, R., Negres-Sadargues, G., Lenel, R. (1982). General survey of carotenoids in crustaceans. In: Britton, G., Goodwin, T. (eds.) Carotenoid chemistry and biochemistry. Oxford University Press, London, p. 221-224

Checkley, D. M., Jr. (1980). Food limitation of egg production by a marine planktonic copepod in the sea off southern California. Limnol. Oceanogr. 25: 991-998

Cheeseman, D. F., Lee, W. L., Zegalsky, P. F. (1967). Carotenoproteins in invertebrates. Biol. Rev. 42: 132-160

Conley, W. J., Turner, J. T (1987). Omnivory by the coastal marine copepods Centropages hamatus and Labidocera aestiva. Mar Ecol. Prog. Ser. 21: 113-120

Dagg, M. J., Walser, W. E., Jr. (1986). The effect of food concentration on fecal pellet size in marine copepods. Limnol. Oceanogr. 31: 1066-1071

Davies, B. H. (1965). Carotenoids. In: Goodwin. T. W. (ed.) Chemistry and biochemistry of plant pigments. Academic Press, London, p. 489-532

Downs, J. N., Lorenzen, C. J. (1985). Carbon:pheopigment ratios of zooplankton fecal pellets as an index of herbivorous feeding. Limnol. Oceanogr. 28: 1024-1036

Durbin, E. G., Durbin, A. G., Smayda, I J., P. G. Verity. (1983). Food limitation of production by adult Acartia tonsa in Narragansett Bay, Rhode Island. Limnol. Oceanogr. 30: $1024-1036$

Falkowski, P. G., Vidal, J., Hopkins, T S., Rowe, G. T., Whitiedge, T E., Harrison, W. G. (1983). Summer nutrient dynamics in the Middle Atlantic Bight: primary production and utilization of phytoplankton carbon. J. Plankton Res. 5: 515-537

Gieskes, W W. C, Kraay, G. W (1986). Phytoplankton, its pigments and primary production at a central North Sea station in May, July and September 1981. Neth. J. Sea Res. 18: $51-70$

Gifford, D. J., Dagg, M. J. (1987). Consumption of ciliate microzooplankton by Neocalanus plumchrus in the subarctic north Pacific Ocean. EOS 68: 1705

Hairston, N. G., Jr (1979). The effect of temperature on carotenoid photoprotection in the copepod Diaptomus nevadensis. Comp. Biochem. Physiol. 62A: 445-448

Hairston, N. G., Jr. (1980). On diel variation in copepod pigmentation. Limnol. Oceanogr 25: 742-746

Hallegraeff, G. M. (1981). Seasonal study of phytoplankton pigments and species at a coastal station off Sydney: importance of diatoms and nanoplankton. Mar Biol. 61: $107-118$

Hallegraeff, G. M., Mous, L. J., Veeger, R., Flick, J. G. Ringelberg, J. (1978). A comparative study of the carotenoid pigmentation of the zooplankton of Lake Marseveen (Netherlands) and Lac Pavin (Auvergne, France). 2. Diurnal variations in carotenoid content. Comp. Biochem. Physiol. 60: 59-62

Heinle, D. R., Harris, R. P., Ustach, J. F., Flemer, D. A. (1977). Detritus as a food for estuarine copepods. Mar. Biol. 40: $341-353$

Herring, P. J. (1972). Depth distribution of the carotenoid pigments and lipids of some oceanic animals. 1. Mixed zooplankton, copepods and euphausids, J. mar. biol. Ass. U. K. 52: 179-189

Hitchcock, G. L. (1986). Methodological aspects of timecourse measurements of $14 \mathrm{C}$ fixation in marine phytoplankton. J. exp. mar. Biol. Ecol. 95: 233-243 
Jeffrey, S. W. (1974). Profiles of photosynthetic pigments in the ocean using thin layer chromatography. Mar. Biol. 26 : $101-110$

Klein, B., Gieskes, W., Kray, G. G. (1986). Digestion of chlorophylls and carotenoids by the marine protozoan Oxyrrhis marina studied by h.p.l.c. analysis of algal pigments. J. Plankton Res. 8: 827-836

Kleppel, G. S. (1987). Diet and egg production of the copepod Acartia tonsa off southern California. EOS 68: 1731

Kleppel, G. S. (1988). Plant and animal pigments as trophodynamic indicators. In: Soule, D. F., Kleppel, G. S. (eds.) Marine organisms as indicators. Springer-Verlag, New York, p. 73-90

Kleppel, G. S., Manzanilla, E. (1983). Analyses of feeding in two copepods from Santa Monica Bay, California. Fish. Bull. U. S. $81 \cdot 154-161$

Kleppel, G. S., Pieper, R. E. (1984). Phytoplankton pigments in the gut contents of planktonic copepods from coastal waters off southern California. Mar. Biol. 78: 193-198

Kleppel, G. S., Pieper, R. E., Trager, G. (1988). Variability in the gut contents of individual Acartia tonsa from waters off southern California, Mar Biol. 97: 185-190

Kleppel, G. S., Willbanks, L. Pieper, R. E. (1985). Diel variation in body carotenoid content and feeding activity in marine zooplankton assemblages. J. Plankton Res. 7: 569-580

Krinsky, N. I. (1971). Function. In: Isler, O. (ed.) Carotenoids. Birkhäuser, Basel, p. 669-716

Landry, M. R. (1981). Switching between herbivory and carnivory by the planktonic marine copepod Calanus pacificus. Mar. Biol. 65: 77-82

Liaaen-Jensen, S. (1979). Carotenoids - a chemosystematic approach. Pure appl. Chem. 51: 661-675

Lonsdale, D. J., Heinle, D. R., Siegfried, C. (1979). Carnivorous feeding by the adult calanoid copepod Acartia tonsa Dana. J. exp. Mar. Biol. Ecol. 36: 235-248

Mackas, D., Bohrer, R. (1976). Fluorescence analysis of zooplankton gut contents and an investigation of diel feeding patterns. J. exp. mar Biol. Ecol. 25: 77-85

Mantoura, R. F., Llewellyn, C. A. (1983). The rapid determination of algal chlorophyll and carotenoid pigments and their degradation products in natural waters by reverse-phase high performance liquid chromatography. Analyt. Chim. Acta 151: $297-314$

Marshall, S. M. (1924). The food of Calanus finmarchicus during 1923. J. mar. biol. Ass. U. K. 13: 473-479

Morey-Gaines, G. (1980). The ecological role of dinoflagellate blooms in the Los Angeles-Long Beach Harbor. Ph. D. thesis, University of Southern California, Los Angeles

Mullin, M. M. (1966). Selective feeding by calanoid copepods from the Indian Ocean. In: Barnes H. (ed.) Some contemporary studies in marine science. Allen and Unwin, London, p. 545-554

Nelson, J. R. (1986). Phytoplankton carotenoids as organic tracers in marine particulate organic matter. Ph. D. thesis, University of California, San Diego

Paanakker, J. E., Hallegraeff, G. M. (1978). A comparative study of carotenoid pigmentation of the zooplankton of Lake Maarsseveen (Netherlands) and Lac Pavin (Auvergne, France). I. Chromatographic characterization of carotenoid pigments. Comp. Biochem. Physiol. 60B: $51-58$

Rassoulzadegan, F., Sheldon, R. W. (1986). Predatory-prey interactions of nanozooplankton and bacteria in an oligotrophic marine environment. Limnol. Oceanogr. 31: 1010-1021

Repeta, D. J., Gagosian, R. B. (1982). Carotenoid transformation products in coastal marine waters. Nature, Lond. 295 $51-54$

Repeta, D. J., Gagosian, R. B. (1983). Carotenoid transformation products in the upwelled waters off the Peruvian coast: suspended particulate matter, sediment trap material and zooplankton fecal pellet analyses. Advances in Geochemistry, 1981. John Wiley \& Sons, London, p. 380-388

Ringelberg, J. (1980). Aspects of red pigmentation in zooplankton, especially copepods. In: Kerfoot, W. C. (ed.) Evolution and ecology of zooplankton communities. University of New Hampshire Press, Hanover, p. 91-97

Roman, M. R. (1977). Feeding of the copepod Acartia tonsa on the diatom Nitzchia closterium and on brown algae (Fucus vesiculosus) detritus. Mar. Biol. 42: 149-156

Roman, M. R. (1984). Utilization of detritus by the copepod Acartia tonsa. Limnol. Oceanogr. 29: 949-959

Roman, M. R., Reeve, M. R., Froggart, J. L. (1983). Carbon production and export from Biscayne Bay, Florida. I. Temporal patterns in primary production, seston and zooplankton. Estuar Coast. Shelf Sci. 17: 45-61

Sheldon, R. W., Nival, P., Rassoulzadegan, F. (1986). An experimental investigation of a flagellate-ciliate-copepod food chain with some observations relevant to the linear biomass hypothesis, Limnol. Oceanogr. 31: 184-188

Sherr, E. B., Sherr, B. F., Paffenhöfer, G.-A. (1986). Phagotrophic protozoa as food for metazoans: a missing trophic link in marine pelagic food webs? Mar. microb. Food Webs 1: $61-80$

Smith, R. C., Bidigare, R. R., Prezlin, B. B., Baker, K. S., Brooks, J. M. (1987). Optical characterization of primary productivity across a coastal front. Mar. Biol. 96: 575-591

Snyder, L. R., Kirkland, J. J. (1979). Introduction to modern liquid chromatography, 2nd edn. John Wiley \& Sons, New York

Stoecker, D. K., Egloff, D. A. (1987). Predation by Acartia tonsa Dana on planktonic ciliates and rotifers. J. exp. mar. Biol. Ecol. 110: 53-68

Stoecker, D. K., Sanders, N. K. (1985). Differential grazing by Acartia tonsa on a dinoflagellate and a tintinnid. J. Plankton Res. 7: 85-100

Strain, H. H., Manning, W. M., Harding, G. (1944). Xanthophylls and corotenes of diatoms, brown algae, dinoflagellates, and sea anemones. Biol. Bull mar biol. Lab., Woods Hole 86: 169-191

Strathmann, R. R. (1967). Estimating the organic carbon content of phytoplankton from cell volume or plasma volume. Limnol. Oceanogr 12: 411-418

Turner, J. T., Anderson, D. M. (1984). Zooplankton grazing during dinoflagellate blooms in a Cape Cod embayment, with observations of predation upon tintinnids by copepods. P.S.Z.N.I. Mar. Ecol. 4: 359-374

Tuttle, R. C., Loeblich, A. R., III, Smith, V. E. (1973). Carotenoids of Cryptothecodinium cohni. J. Protozool. 20: 521

Wiebe, P. H., Boyd, S., Cox, J. L. (1975). Relationships between zooplankton displacement volume, wet weight, dry weight and carbon. Fish. Bull. U. S. 73: 777-786 